\title{
Interactive comment on "Regional-scale modelling for the assessment of atmospheric particulate matter concentrations at rural background locations in Europe” by Goran Gašparac et al.
}

Goran Gašparac et al.

gorangas@gmail.com

Received and published: 2 February 2020

Dear Reviewer, please find comments in the pdf and proofreading confirmation on the following link: https://www.dropbox.com/s/5kk3ckkf7jsddv5/GJKG_certificate_N4ZB49MT-21D42086-C842-302A-784E.pdf?dl=0

Please also note the supplement to this comment: supplement.pdf 
Interactive comment on Atmos. Chem. Phys. Discuss., https://doi.org/10.5194/acp-2019-389, 2019.

\section{ACPD}

Interactive

comment 